Provided for non-commercial research and education use. Not for reproduction, distribution or commercial use.

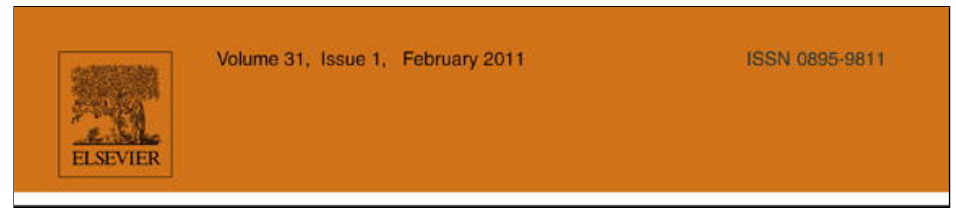

Journal of

South American Earth Sciences

Including Mexico, Central America, The Caribbean and the Antarctic Peninsula

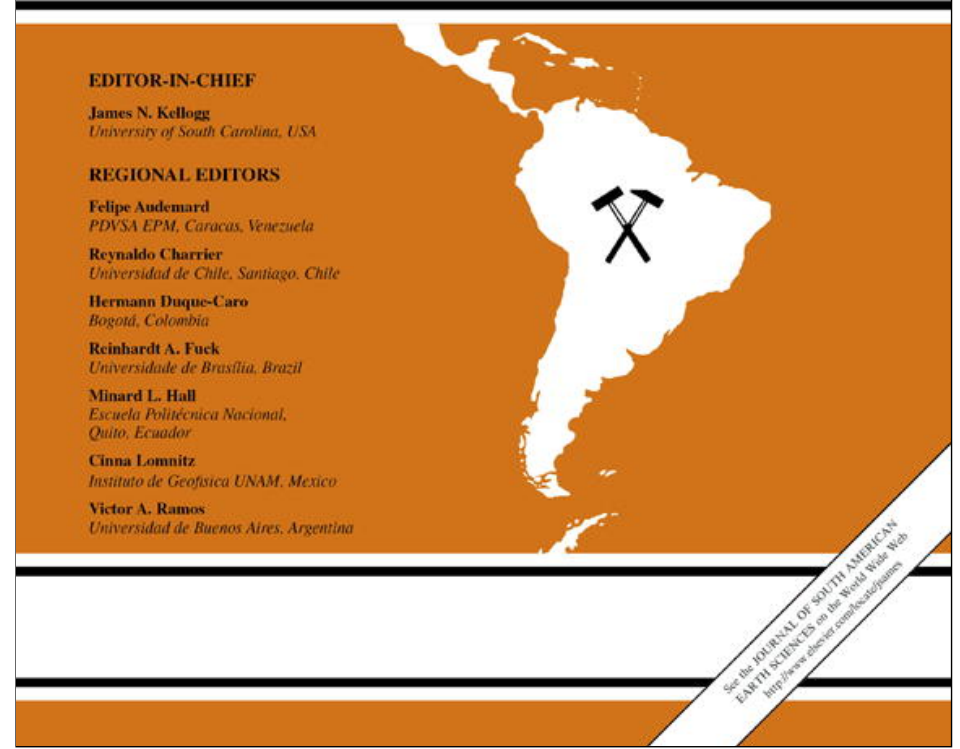

(This is a sample cover image for this issue. The actual cover is not yet available at this time.)

This article appeared in a journal published by Elsevier. The attached copy is furnished to the author for internal non-commercial research and education use, including for instruction at the authors institution and sharing with colleagues.

Other uses, including reproduction and distribution, or selling or licensing copies, or posting to personal, institutional or third party websites are prohibited.

In most cases authors are permitted to post their version of the article (e.g. in Word or Tex form) to their personal website or institutional repository. Authors requiring further information regarding Elsevier's archiving and manuscript policies are encouraged to visit:

http://www.elsevier.com/copyright 


\title{
Modeling a tsunami from the Nicoya, Costa Rica, seismic gap and its potential impact in Puntarenas
}

\author{
Silvia E. Chacón-Barrantes ${ }^{\mathrm{a}, 1}$, Marino Protti ${ }^{\mathrm{b}, *}$ \\ a Laboratorio de Oceanografía, Departamento de Física, Universidad Nacional, Heredia, Costa Rica \\ ${ }^{\mathrm{b}}$ Observatorio Vulcanológico y Sismológico de Costa Rica (OVSICORI-UNA), Universidad Nacional, Apartado 1718-3000, Heredia, Costa Rica
}

\section{A R T I C L E I N F O}

\section{Article history:}

Received 9 June 2010

Accepted 14 March 2011

\section{Keywords:}

Tsunami

Costa Rica

Puntarenas

Nicoya seismic gap

Nicoya gulf

Nicoya peninsula

\begin{abstract}
A B S T R A C T
Although subduction zones around the world are known to be the source of earthquakes and/or tsunamis, not all segments of these plate boundaries generate destructive earthquakes and catastrophic tsunamis. Costa Rica, in Central America, has subduction zones on both the Pacific and the Caribbean coasts and, even though large earthquakes ( $\mathrm{Mw}=7.4-7.8$ ) occur in these convergent margins, they do not produce destructive tsunamis. The reason for this is that the seismogenic zones of the segments of the subduction zones that produce large earthquakes in Costa Rica are located beneath land (Nicoya peninsula, Osa peninsula and south of Limón) and not off shore as in most subduction zones around the world. To illustrate this particularity of Costa Rican subduction zones, we show in this work the case for the largest rupture area in Costa Rica (under the Nicoya peninsula), capable of producing Mw $\sim 7.8$ earthquakes, but the tsunamis it triggers are small and present little potential for damage even to the largest port city in Costa Rica.

The Nicoya seismic gap, in NW Costa Rica, has passed its 50-year interseismic period and therefore a large earthquake will have to occur there in the near future. The last large earthquake, in 1950 generated a tsunami which slightly affected the southwest coast of the Nicoya Peninsula. We present here a simulation to study the possible consequences that a tsunami generated by the next Nicoya earthquake could have for the city of Puntarenas. Puntarenas has a population of approximately eleven thousand people and is located on a $7.5 \mathrm{~km}$ long sand bar with a maximum height of $2 \mathrm{~m}$ above the mean sea level. This condition makes Puntarenas vulnerable to tsunamis.
\end{abstract}

(C) 2011 Elsevier Ltd. All rights reserved.

\section{Introduction}

Subduction zones around the world are the source of earthquakes and/or tsunamis and therefore understanding their potential to generate damage to people and infrastructure is of general interest. But not all segments of these plate boundaries generate destructive earthquakes and catastrophic tsunamis. Some don't even produce large earthquakes (Marianas). Others, like Nicaragua, have large earthquakes without direct seismic damage but they trigger large tsunamis (Ide et al., 1993; Satake, 1994), and others produce large earthquakes but small tsunamis. Costa Rica, in Central America, has subduction zones on both the Pacific and the Caribbean coasts (Fig. 1 ). Large earthquakes ( $\mathrm{Mw}=7.4-7.8$ ) occur

\footnotetext{
* Corresponding author. Tel.: +506 2562 4001; fax: +506 22610303.

E-mail addresses: silviachaconb@gmail.com (S.E. Chacón-Barrantes), jprotti@ una.ac.cr (M. Protti).

1 Present address: Coastal Research Laboratory (CORELAB), Christian-Albrechts University, Otto-Hahn-Platz 3, D-24118 Kiel, Germany. Fax: +49 4318807303.
}

in these convergent margins but they do not produce destructive tsunamis. The reason for this is that the seismogenic portions of the segments of the subduction zones that produce large earthquakes in Costa Rica are located beneath land (Nicoya peninsula, Osa peninsula and south of Limón) and not off shore as in most subduction zones around the world (Protti and González, 2007). The deformation of the ocean floor is therefore minimal and the tsunamis generated are small. We illustrate this particularity of the Costa Rica subduction zones, showing the extreme case for the largest rupture area in Costa Rica (under the Nicoya peninsula, capable of producing $\mathrm{Mw} \sim 7.8$ earthquakes) and demonstrate that the tsunamis it triggers are small and present little potential for damage even to the largest port city in Costa Rica.

Costa Rica has nearly $1500 \mathrm{~km}$ of coastline; most of it (85\%) on the Pacific side (IGN, 2005). This condition makes Costa Rica vulnerable to tsunamis because $83 \%$ of the tsunamis for which there is some type of record (Farreras, 1997) have occurred in the Pacific Ocean. Also, off the Pacific coast of Costa Rica lies the Middle American Trench, where the Cocos plate subducts under both the Caribbean plate and the Panama block, generating very frequent 


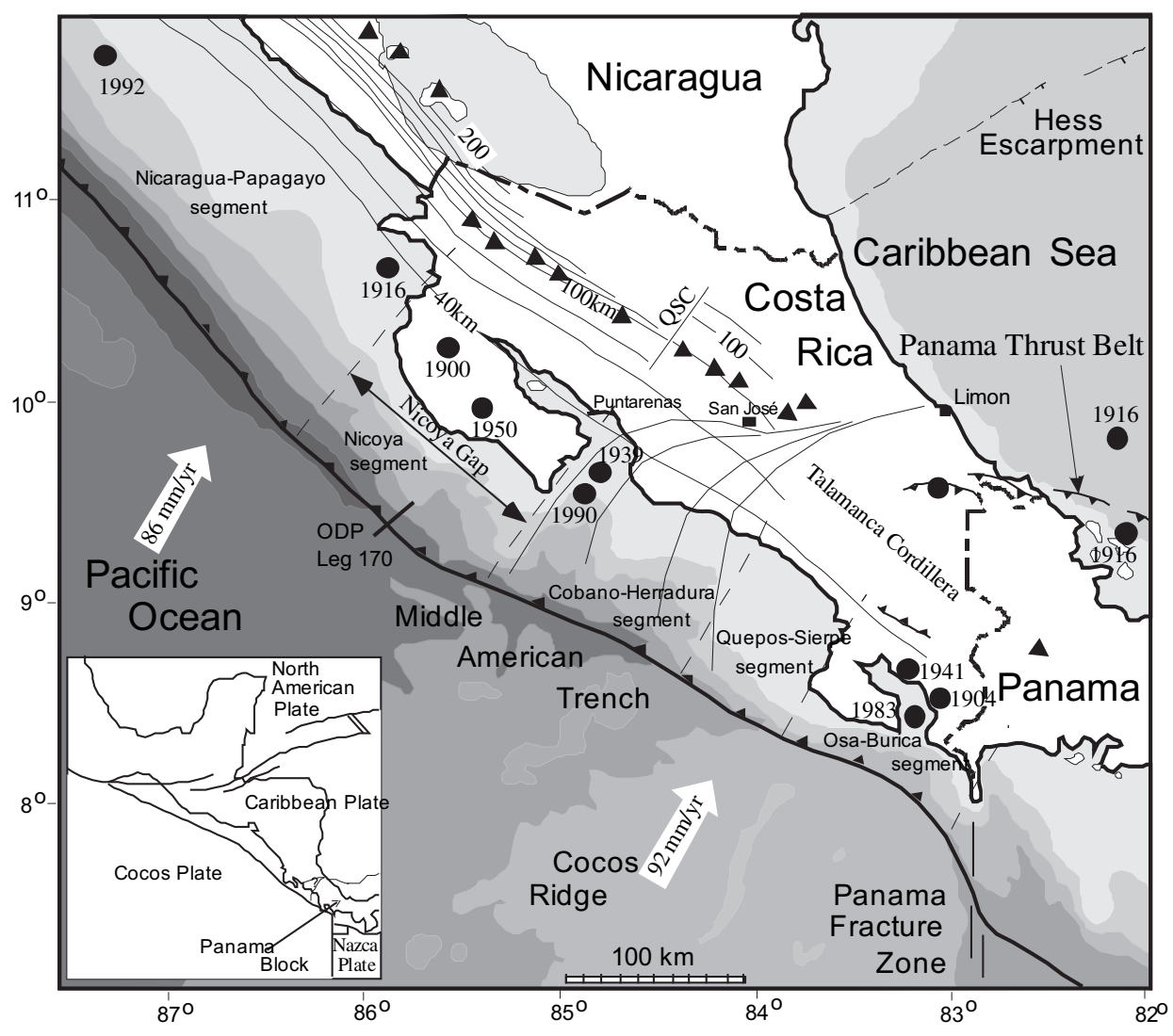

Fig. 1. Local tectonics of Costa Rica and geometry of the Wadati-Benioff zone (from Protti et al., 1995b). Isodepth contours to the top of the seismic slab are at 20 km intervals, starting at $40 \mathrm{~km}$. Filled triangles represent active volcanoes and filled circles the location of large (Mw $\geq 7.0)$ earthquakes that occurred in the twentieth century. QSC marks the projection of the Quesada Sharp Contortion.

seismic activity of shallow source, appropriate conditions for tsunami generation.

The city of Puntarenas is located on the eastern side of the Nicoya Gulf. It is on a sand bar of $7.5 \mathrm{~km}$ in length, which at its widest measures only $600 \mathrm{~m}$ (Fig. 2). Its maximum height is approximately $2 \mathrm{~m}$ above mean sea level and presents a tide range of approximately $2.8 \mathrm{~m}$. For a length of about $1 \mathrm{~km}$ along this sand bar there is a single two-lane terrestrial access and evacuation route, 30 m wide, known as La Angostura (the narrow one). This section of the sand bar is subject to traffic congestion during special events and would likely be inadequate in case of disaster.

Puntarenas is the administrative capital of the province with the same name (Fig. 2). It has a population close to eleven thousand people and, until the mid 1980s, it was the main port along the Pacific coast of Costa Rica. The main port now is only $15 \mathrm{~km} \mathrm{SE}$ from Puntarenas, still on the Gulf of Nicoya. Today Puntarenas' main economical activity is tourism. In addition to the tourists who visit Puntarenas, every year hundreds of thousand people use the ferries that cross the Gulf of Nicoya to the Nicoya peninsula. The old commercial pier is now a tourist pier where large cruise ships dock every week. During special events and holidays, the avenue parallel to the beach, called Paseo de los Turistas (Walk of the Tourists), is closed to vehicles to allow people to gather along it.

The recognition of a mature seismic gap, the Nicoya seismic gap, just west of the coastal city of Puntarenas, with potential to generate a $\sim \mathrm{Mw}=7.8$ earthquake (Protti et al., 2001; Gonzalez and Protti, 2005) on the subduction zone, together with the recent images of the 2004 Sumatra Tsunami, have triggered valid concerns among the general population and authorities of Puntarenas. We present here a plausible model for the tsunami that could be generated by the next Nicoya earthquake and show how it could potentially affect the Puntarenas sand bar.

Previous studies have researched the possible consequences that a tsunami would have for the city of Puntarenas. Ortiz et al. (2001) analyzed the arrival at Puntarenas of a tsunami from three different sources: one originated by an earthquake at the entrance of the Gulf of Nicoya, with a dislocation of $6 \mathrm{~m}$; another originated by an earthquake with similar focal mechanism to that suggested by Barquero and Boschini (1991) for the 1990 Cóbano earthquake, and the last tsunami they modeled from an event with similar characteristics to the January 31st, 1906, Colombia earthquake.

The two seismic scenarios analyzed here differ from those analyzed by Ortiz et al. (2001). We use an Mw $=7.8$ seismic source under the Nicoya peninsula (Gonzalez and Protti, 2005), and we use the focal mechanism (pure thrust), location (entrance of the Nicoya gulf) and size $(\mathrm{Mw}=7.0)$ of the 1990 Cóbano earthquake, published by Protti et al. (1995a).

Ureña (2005) also used a source from the Nicoya seismic gap to model a tsunami arriving at Puntarenas 40 min after rupture. His resulting deformation pattern shows uplift off the Nicoya peninsula and subsidence along the gulf; Puntarenas lies outside his deformation region. In his work he employed seismic parameters that are estimates from more than ten years ago, before the NSF-MARGINS Seismogenic Zone Experiment (SEIZE) initiative that, since 1999, has been providing detailed information on the plate interface and the nature of, and seismic potential for, the Nicoya seismic gap (Protti et al., 2001; Newman et al., 2002; Norabuena et al., 2004; Iinuma et al., 2004 and DeShon et al., 2006). Additionally, Ureña (2005) considered the rupture of the Nicoya seismic gap along a dipping surface with a constant angle over the entire seismogenic zone, 

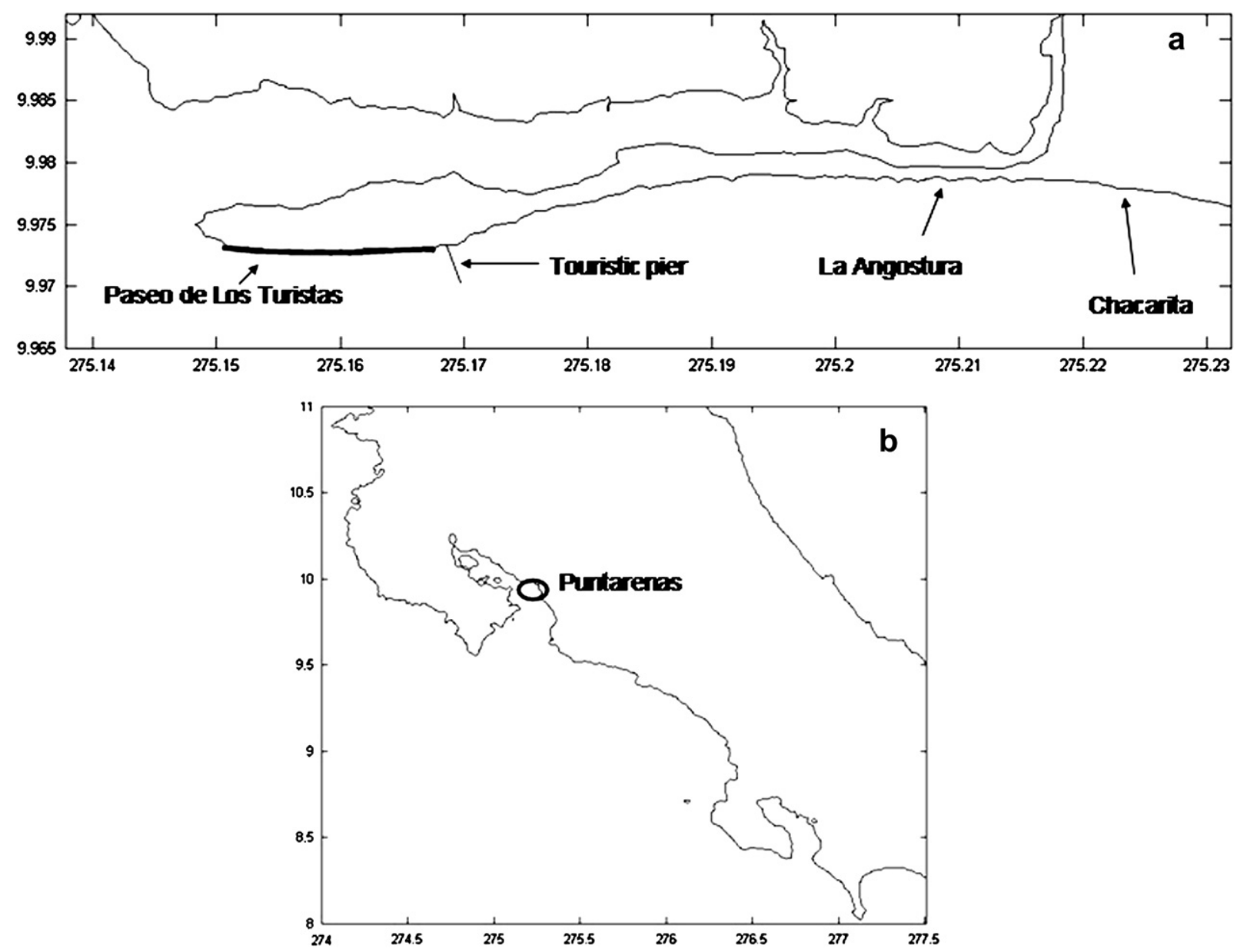

Fig. 2. (a). Map of Puntarenas showing location of places mentioned in the text. (b). Map of Costa Rica showing portion depicted in Fig. 2a.

while in this work we consider an inter plate surface with a shallow, low dipping surface followed down dip by a steeper surface, resulting in a different deformation pattern to that obtained by Ureña (2005).

\section{Tectonic setting of Costa Rica}

Central America is located on the western margin of the Caribbean Plate and on the Panama Block (inset in Fig. 1). In its central and northern portions, the Cocos Plate subducts beneath the Caribbean Plate, and in the southeast, under the Panama block. This subduction occurs along the Middle America Trench at a rate between 70 and $95 \mathrm{~mm} /$ year from Guatemala to southern Costa Rica, respectively (computed from De Mets et al., 1990). In central Costa Rica, the boundary between the Caribbean Plate and the Panama Block is not yet well developed and consists of a diffuse left lateral shear zone that runs from Limón to the Middle American Trench (Fig. 1) (Ponce and Case, 1987; Jacob and Pacheco, 1991; Güendel and Pacheco, 1992; Goes et al., 1993; Fan et al., 1993; Fisher et al., 1994; Protti and Schwartz, 1994; Marshall et al., 2000). South of the border between Costa Rica and Panama, off the Burica Peninsula, is the Panama Fracture Zone. This right-lateral transform fault is the plate boundary between the Cocos and Nazca Plates and has been the source of several events that have resulted in damage in Costa Rica and Panama.

Due to this tectonic environment, Costa Rica is a very active region with seismic sources of different genesis and depths. Shallow events $(Z<30 \mathrm{~km})$ occur: (a) associated with the subduction of the Cocos
Plate under the Caribbean Plate and Panama Block; (b) along the Panama Fracture Zone; (c) as intra plate faulting of the Panama Block and the Cocos and Caribbean Plates; (d) as inter plate activity between the Caribbean Plate and the Panama Block, both along the Panama Thrust Belt and along the shear zone across central Costa Rica; and (e) associated with the volcanic arc. Intermediate depth earthquakes in Costa Rica occur as internal deformation of the subducted Cocos Plate under the Caribbean Plate and Panama Block. The maximum depth of intra slab earthquakes in Costa Rica decreases from $220 \mathrm{~km}$ under the border between Nicaragua and Costa Rica, to around $60 \mathrm{~km}$ in southern Costa Rica (Protti et al., 1995b).

\subsection{Segmentation of the subduction zone off Costa Rica}

The subduction, under Nicaragua and Costa Rica, of Cocos plate lithosphere with different genesis and geomorphic features, results in very important along-the-trench changes in the way it interacts with the upper plate. The elastic coupling between the Cocos and Caribbean plates, as well as between the Cocos plate and the Panama block, changes dramatically from NW to SE (Protti-Quesada, 1991; Protti et al., 1995b). These changes correlate well with the bathymetric features on the subducting ocean floor, which are directly related to the genesis and age of the Cocos plate. The age of the Cocos plate controls the subduction angle, the maximum depth of coupling and the depth of the deepest intra plate seismicity. The bathymetric features on the ocean floor control the size and lateral extension of the asperities that constitute the seismogenic zone. 


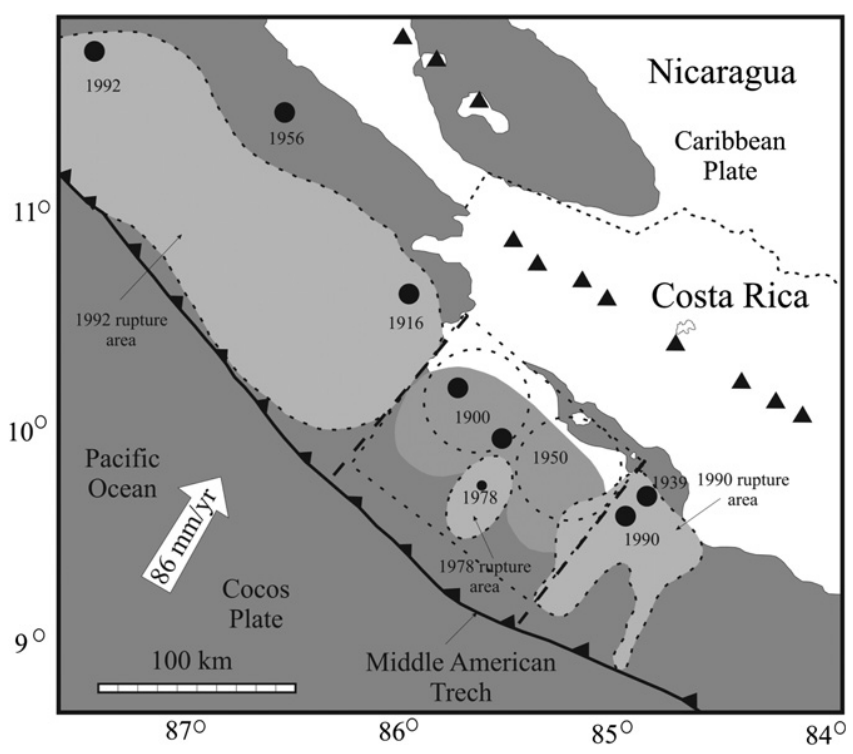

Fig. 3. Definition and localization of Nicoya seismic gap. The rectangle and the circles of discontinued lines mark the maximum and minimum limits of the rupture area of the next earthquake according to Protti et al. (2001).

Based on the above mentioned differences, and both historically and instrumentally recorded seismicity, the subduction zone in the southern portion of the Middle American Trench has been divided into five segments (Protti et al., 2001). These segments (Fig. 1) are: (1) Nicaragua-Papagayo, (2) Nicoya, (3) Cóbano-Herradura, (4) Quepos-Sierpe and (5) Osa-Burica. Cocos plate lithosphere created along the East Pacific Rise subducts under the Caribbean plate in the first two segments, while Cocos plate created along the Galapagos Spreading Center subducts under the Panama block in the last two segments and under a transition between Caribbean plate and Panama block under the Cóbano-Herradura segment (Fig. 1).

In this work we model tsunamis generated by sources from the Nicoya and Cóbano-Herradura segments. Relatively old lithosphere, with smooth bathymetry, subducts under the Nicoya segment. The lithostatic load applied by the peninsula over the plate interface increases the normal stress and therefore the coupling between the two plates. Given this strong coupling, the Nicoya segment is characterized by producing large earthquakes ( $\mathrm{Mw}>7.5$ ) with very low background seismicity during the interseismic period. Large earthquakes have occurred in this segment in 1853,1900 and 1950. Young lithosphere with rough bathymetry, made up of several isolated

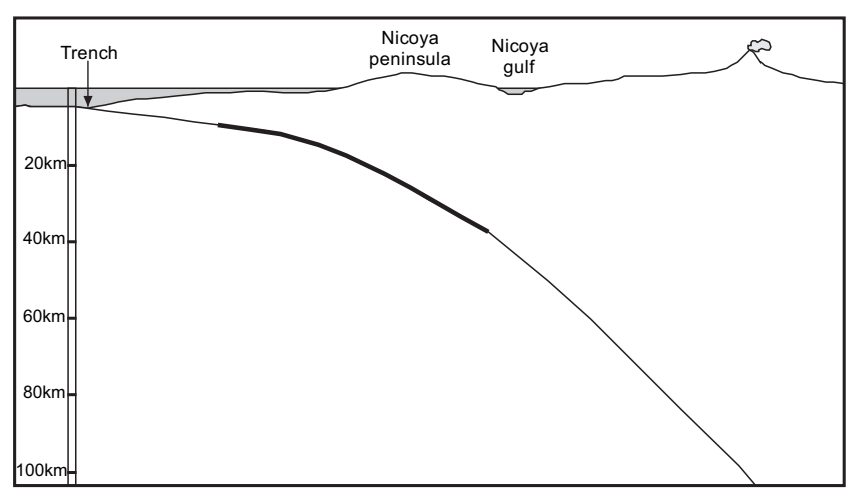

Fig. 4. Geometry of the plate interface under Nicoya peninsula used for the tsunami modeling. The dark section of the plate interface corresponds to the seismogenic zone from Protti et al. (2001). seamounts, subducts under the Cóbano-Herradura segment (Protti et al., 1995b). When subducting, these seamounts reduce the coupling area to a set of small asperities incapable of accumulating large magnitude strain which therefore break frequently with moderate size events. The Cóbano-Herradura segment has had earthquakes with magnitude close to Mw = 7 in 1882,1939 and 1990 (Protti et al., 1995a).

\section{The Nicoya seismic gap}

Seismic gaps have been defined as those segments, along active plate boundaries, that have not experienced the repetition of large earthquakes during the last decades, and therefore are considered as probable sites for the occurrence of future earthquakes (Nishenko, 1985). Thus, seismic gaps represent both a time interval, as well as geographical boundaries, of areas where large earthquakes have occurred in the past but where no significant amount of seismic energy has been released in recent time.

The absence of a large earthquake since October 1950 on the Nicoya segment, and the occurrence of large earthquakes on the neighboring segments of Cóbano-Herradura in 1990, and on the Nicaragua-Papagayo segment in 1992, have allowed the estimation of the geographical extent of what has been defined as the "Nicoya seismic gap" (Protti et al., 2001; Gonzalez and Protti, 2005) (Fig. 3). The Nicoya segment has produced large earthquakes in the past but has very low seismicity during the interseismic periods. This provides insight to the degree of coupling and the characteristics of the next earthquake under the Nicoya peninsula.

As mentioned before, there have been large earthquakes in the Nicoya segment in 1853, 1900 and 1950. This gives a recurrence interval of 52.7 years for 2011, with a standard deviation of 7.4 years.

The March 25, $1990 \mathrm{Mw}=7.0$ earthquake at the entrance of the Gulf of Nicoya marks the SE limit of the Nicoya seismic gap and provided information on the abrupt contrast in inter plate elastic coupling of the seismogenic zone between the Nicoya and the Cobano-Herradura segments: not even a $\mathrm{Mw}=7.0$ earthquake right at the edge of the Nicoya segment was able to trigger rupture and break the Nicoya seismic gap (Protti et al., 1995a).

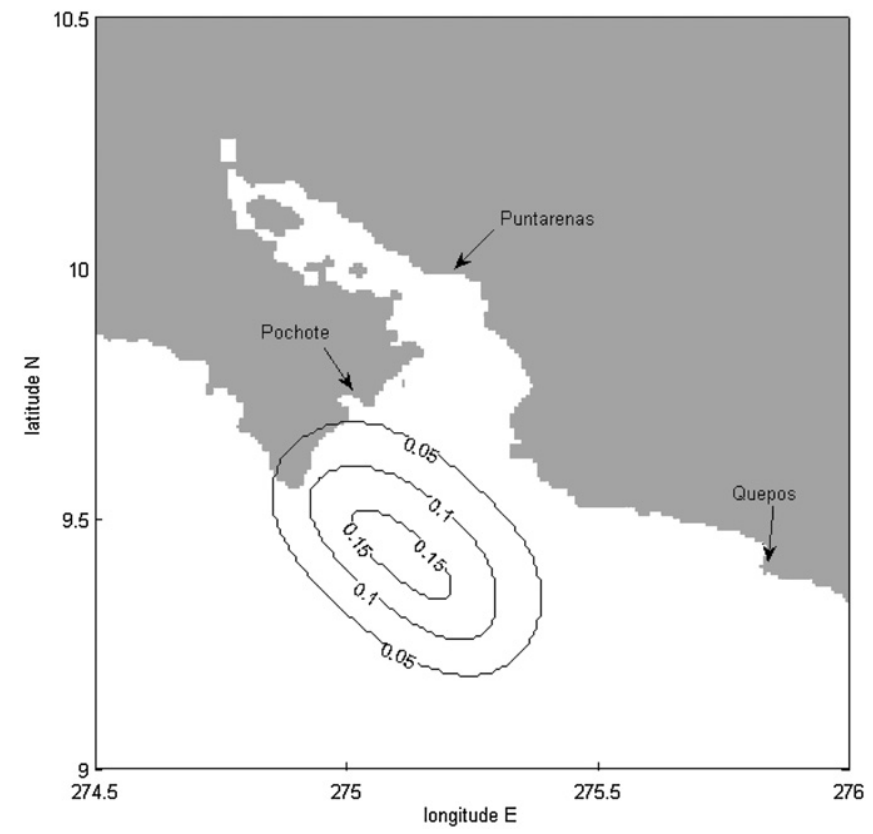

Fig. 5. Simulated co-seismic deformation of the 1990 Cobano earthquake. Contours in meters. Shown also are localities mentioned in the text. 
The NW limit of the Nicoya seismic gap was determined by using the aftershock sequence of the September 2, $1992 \mathrm{Mw}=7.6$ earthquake off Nicaragua. This earthquake ruptured the NW end of the Nicaragua-Papagayo segment and its aftershocks propagated the rupture to the SE, stopping abruptly on the NW end of the Nicoya peninsula.

Landward, the Nicoya seismic gap extends to the axis of the Gulf of Nicoya (Protti et al., 2001) where the plate interface is about $40 \mathrm{~km}$ deep (Protti-Quesada, 1991). Based on both modeling of GPS data by linuma et al. (2004) and Norabuena et al., 2004, as well as on microseismic information obtained by the SEIZE seismic network on the Nicoya peninsula (Newman et al., 2002; DeShon et al., 2006) trenchward, the elastically coupled portion of the seismogenic zone starts some $15 \mathrm{~km}$ from the trench, at depths close to $12 \mathrm{~km}$. However, given the magnitude and amount of potential slip of the future earthquake, its rupture could extend all the way to the trench (Fig. 3 and Fig. 4).

\section{Methodology}

Based on the geophysical information obtained so far, the plate interface between the Cocos and Caribbean plates, under the Nicoya segment, consists of a surface that changes in dip angle from 15 to $28^{\circ}$ from the trench to a depth of $12 \mathrm{~km}$ (just off the west coast of the peninsula) and from there to $40 \mathrm{~km}$ right under the Nicoya gulf, respectively (Fig. 4) (Protti et al., 2001; Newman et al., 2002; DeShon et al., 2005).We attempted to model the deformation along these two dipping planes by solving for each surface and adding up the deformation, but this causes numerical instability in the model in the region where the two surfaces meet. This instability occurs because subsidence induced by slip on the shallow surface gets overprinted by uplift caused by slip on the deeper surface. We then modeled the deformation on a fault surface that averages the dips and depths of these two surfaces combined. However, since the seismogenic zone and the region where most of the slip is expected lies along the lower, steeper dipping surface of the plate interface, the average geometry, mentioned above, artificially reduces the vertical surface deformation during dislocation, by acting on a lower angle and deeper surface. Since, again, most of the slip is expected on the lower surface, we elected to model the deformation and potential tsunami from dislocation along only the lower surface, rather than using an average geometry. This geometry and approach are similar to those used by Marshall and Anderson (1995). Their study utilized the same basic techniques as in this work to evaluate co-seismic uplift/subsidence patterns on the peninsula due to a 1950 style rupture of the Nicoya segment. We later present results assuming that rupture only propagates updip along the shallower surface and show that the subsequent ocean floor deformation is not large enough from the perspective of a potential tsunami.

To compute the surface deformation due to slip along a fault surface we use the model of co-seismic dislocation by Mansinha and Smylie (1971). This model calculates the displacements fields in the surface due to finite, dipping, slip faults using the Volterra's formula (Mansinha and Smylie, 1971).

To estimate the magnitude of the surface deformation that could be produced by an earthquake, it is necessary to know, in addition to the fault geometry, the amount of slip that could potentially occur along the fault during rupture. Four independent studies have computed the percentage of locking along the plate interface under and off the Nicoya peninsula (Lundgren et al., 1999; Protti et al., 2001; Iinuma et al., 2004; Norabuena et al., 2004). All these studies result in $50 \%( \pm 2 \%)$ locking (Gonzalez and Protti, 2005). At a convergence rate of $88 \mathrm{~mm} / \mathrm{yr}$, and assuming the Nicoya 1950, Mw = 7.7 (Pacheco and Sykes, 1992) earthquake released all the previously accumulated slip, we have, after 59 years with $50 \%$ coupling, a total of $2.6 \mathrm{~m}( \pm 10 \mathrm{~cm})$ of potential slip to be released during the next Nicoya earthquake. It is believed that Samara's earthquake of 1978 released only about $15 \%$ of the potential slip accumulated until that date (Protti et al., 2001).

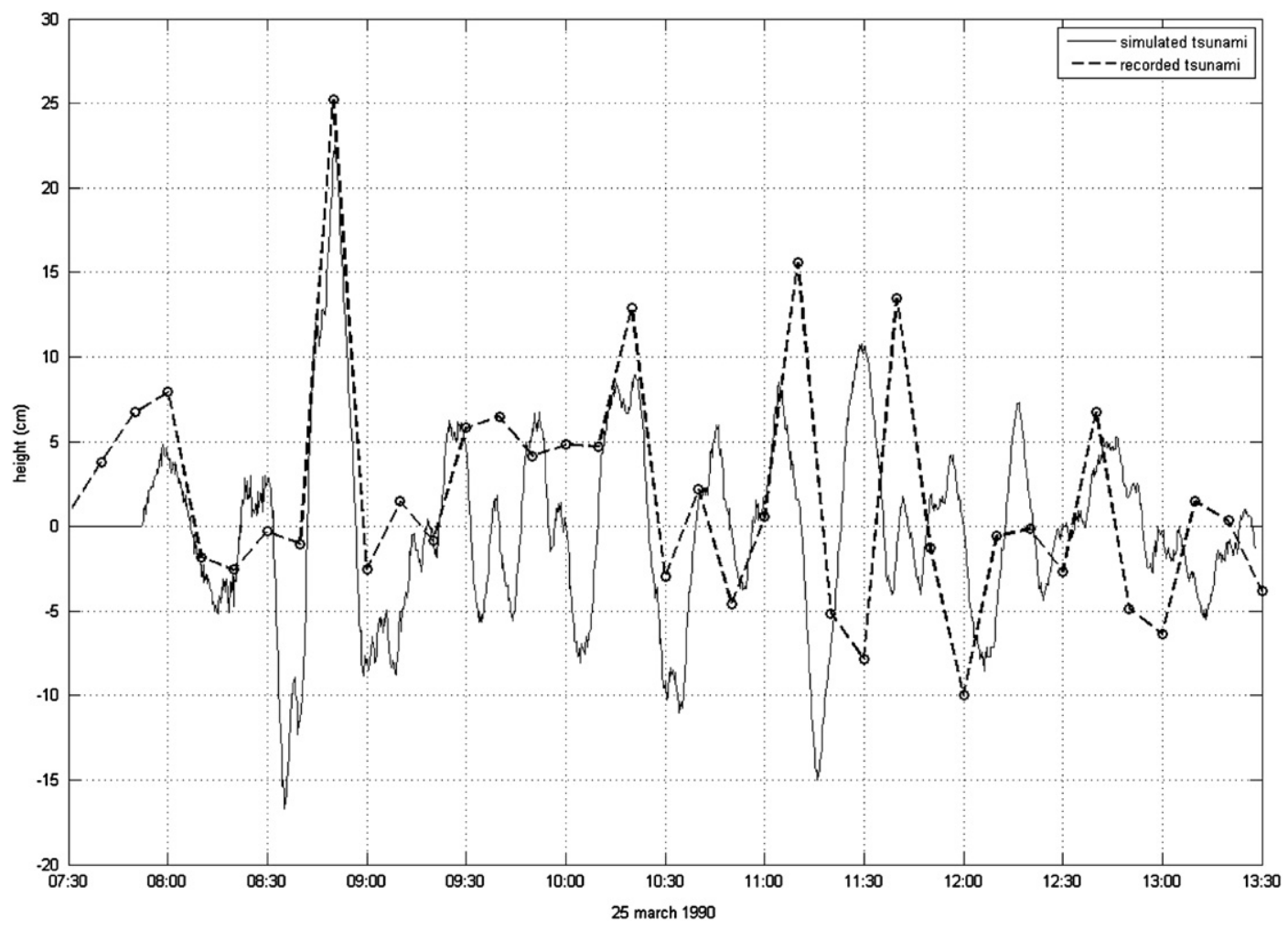

Fig. 6. Comparison between the tsunami records (dashed line and circles) with the simulated tsunami (solid line) for 1990 Cobano tsunami in Quepos. 


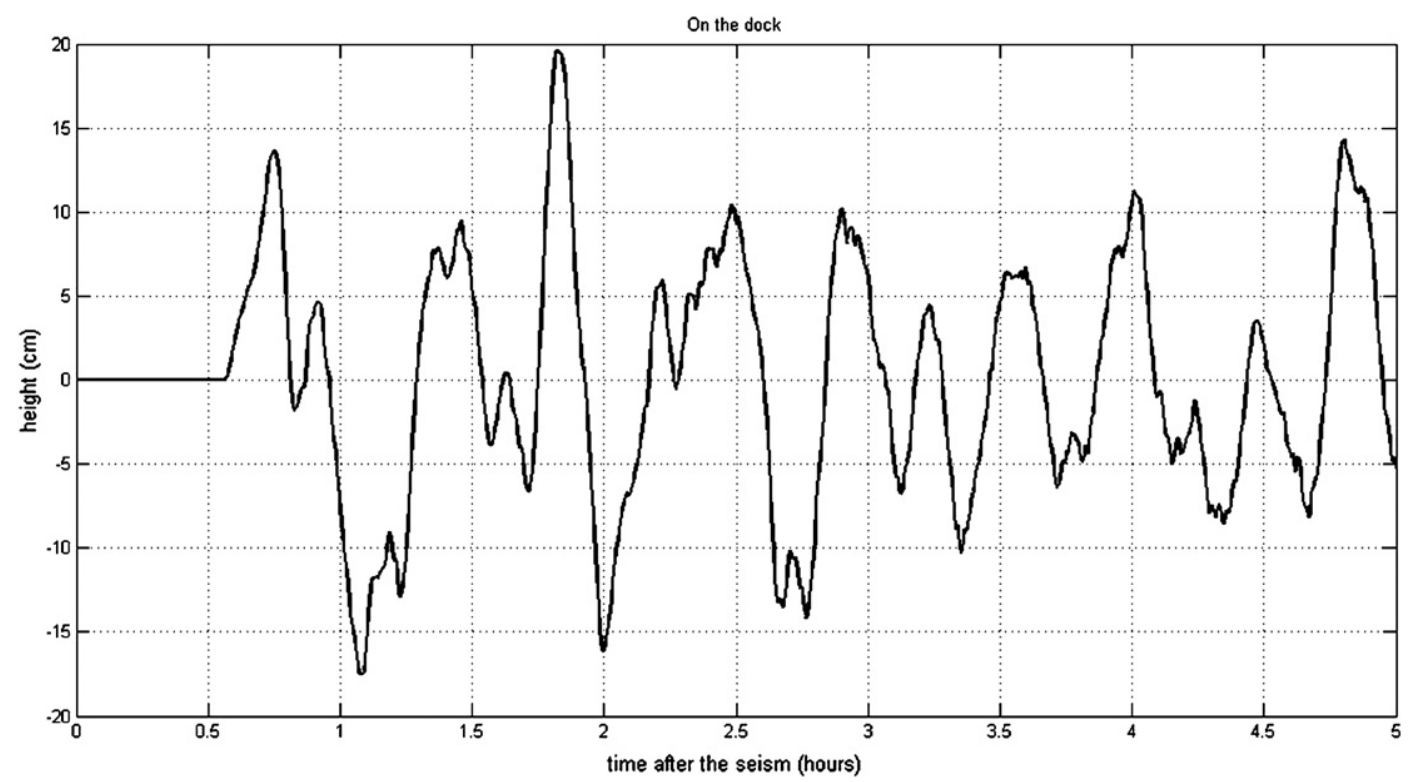

Fig. 7. Simulated 1990 Cóbano tsunami at Puntarenas' dock.

According to the fault surface area analysis of Gonzalez and Protti, 2005 , this amount of slip gives a potential moment magnitude for the next earthquake of $7.8 \pm 0.1$. We model an earthquake of $\mathrm{Mw}=7.8$, corresponding to a rupture plane of $5850 \mathrm{~km}^{2}$ going from $12.5 \mathrm{~km}$ down to nearly $36 \mathrm{~km}$ of depth with a dip angle of $28^{\circ}$.

Assuming the earthquake occurs quickly enough so that the instantaneous deformation of the sea surface is the same as the coseismic deformation, that co-seismic dislocation is used as initial condition of the tsunami in the numerical model of tsunami propagation of Goto et al.(1997), which consists of the numerical solution of the shallow water equations using the leap-frog scheme. In this case four grids of integration are used; an exterior grid which solves the linear shallow water equations, and three interior grids which solve the non-linear shallow water equations. For all of them we used a time step of $1 \mathrm{~s}$. The largest grid includes the whole continental territory of Costa Rica and the subduction zone off the entire Costa Rica Pacific coast with a grid interval of 27 arch-s (approximately $833 \mathrm{~m}$ ). The second grid includes the Nicoya Gulf and has a spatial step of grid of 9 arch-s (approximately $278 \mathrm{~m}$ ). The third and fourth grids include the city of Puntarenas, with spatial steps of grid of 3 arch-s and 1 arch-s

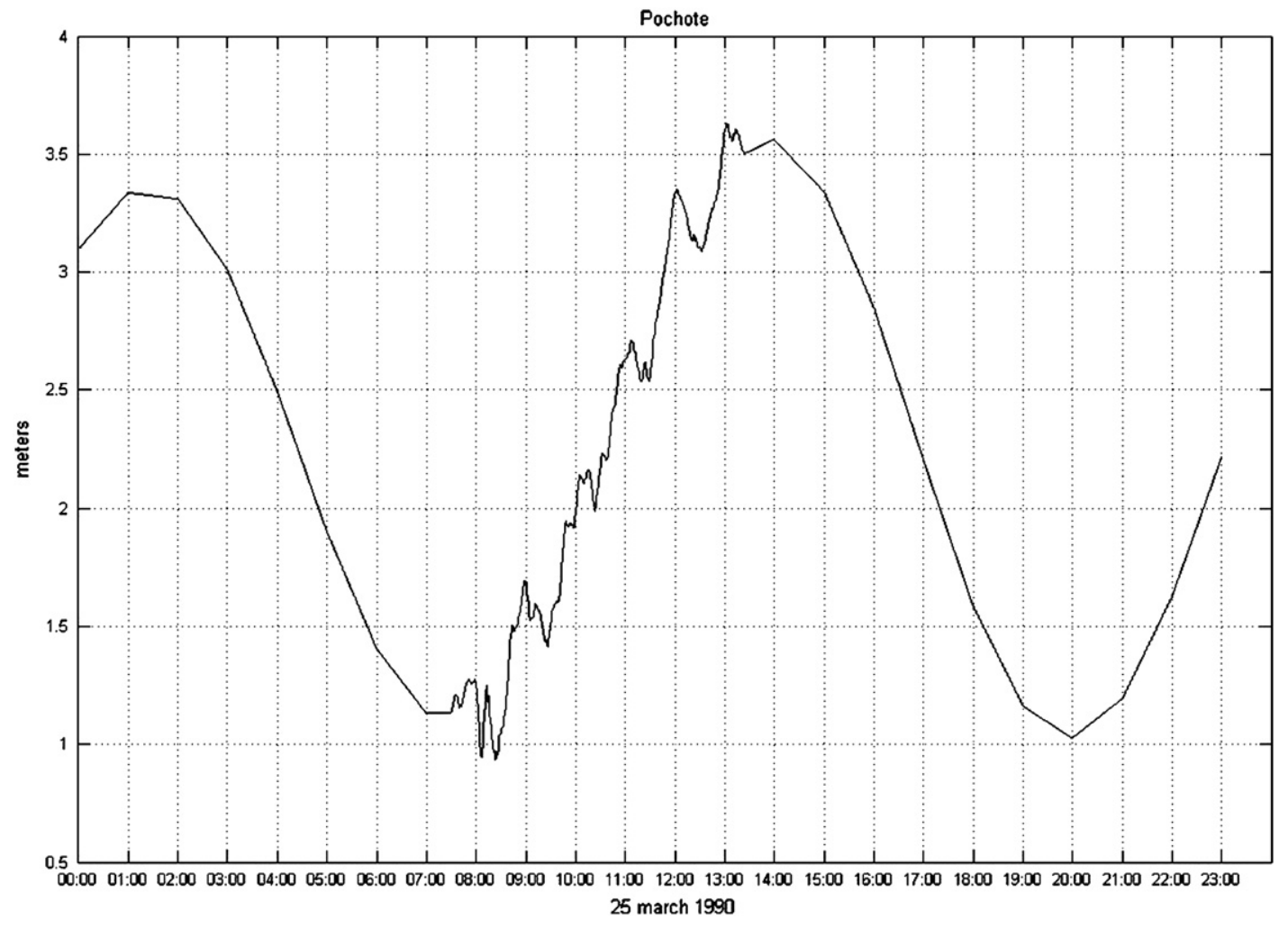

Fig. 8. Tide prediction plus simulated tsunami for Pochote estuary. 1990 Cobano tsunami. 


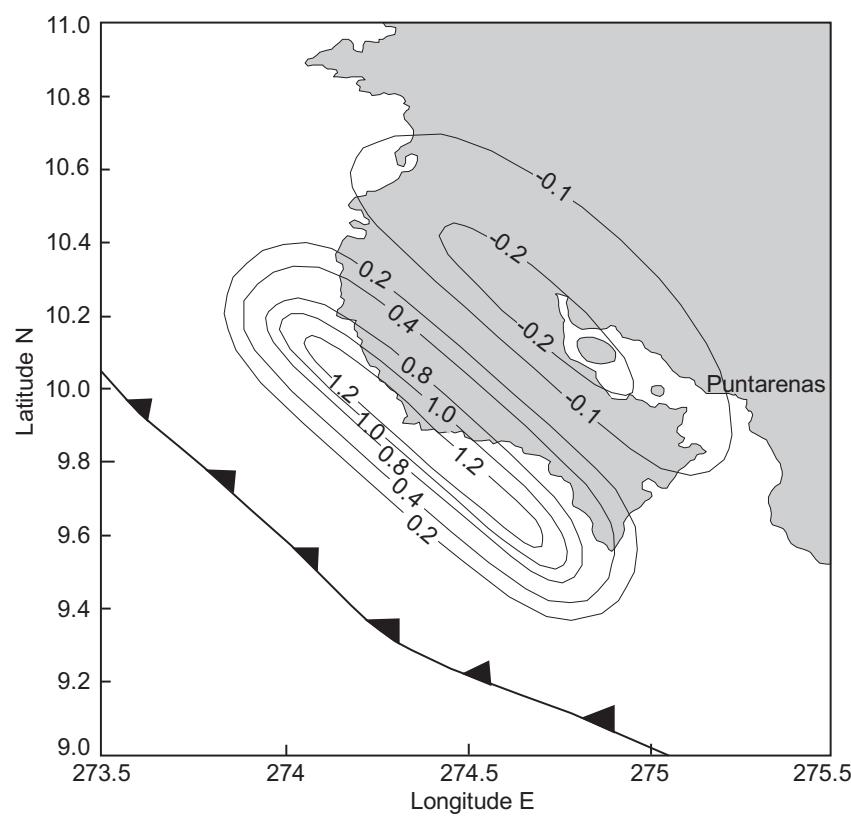

Fig. 9. Vertical deformation pattern simulated for an earthquake $\mathrm{Mw}=7.8$ originated in the Nicoya's seismic gap. Contours in meters. The black tick line shows part of the Middle America Trench.

respectively (approximately $93 \mathrm{~m}$ and $31 \mathrm{~m}$ ), this permits a good resolution for the area of Puntarenas, maintaining the $1 / 3$ proportion between resolutions of consecutive grids.

For the validation of the algorithm used in this work we modeled the tsunami generated by the 1990 earthquake at the entrance of the gulf of Nicoya, and compared it with actual records of the tsunami at the single location where there was a tide gauge at the time of occurrence. This 1990 earthquake had a magnitude $\mathrm{Mw}=7.0$, occurred along the Cobano-Herradura segment, and was interpreted as the rupture of a seamount asperity (Protti et al., 1995a).

\section{Results}

\subsection{The 1990 Cóbano tsunami}

On March 25th, 1990, there was an earthquake of Mw $=7.0$ at the entrance of the Nicoya Gulf (Figs. 1 and 3). This event provoked damage on the Nicoya Peninsula, and in Puntarenas and the Central Valley. It originated from subduction on the Cobano-Herradura segment and it caused a small tsunami which was recorded by a tide gauge at Quepos, some $100 \mathrm{~km}$ south of Puntarenas, on the Central Pacific coast of Costa Rica, with heights of less than $30 \mathrm{~cm}$ (Gutiérrez and Soley, 1991). We chose to simulate this tsunami in order to validate the method and the bathymetry to be employed in modeling a possible tsunami originating at the Nicoya seismic gap.
To determine the co-seismic deformation we used the seismic parameters obtained by Protti et al., 1995a. With that information we set up a rupture plate of $53 \mathrm{~km}$ by $40 \mathrm{~km}$, going from $15 \mathrm{~km}$ down to $35 \mathrm{~km}$ in depth. The dip angle was set as $25.2^{\circ}$ and the mean slip as $45 \mathrm{~cm}$. The resultant co-seismic deformation has a maximum of $+16 \mathrm{~cm}$ (Fig. 5).

Fig. 6 shows the comparison of the tsunami recorded by the tide gauge at Quepos with the simulated tsunami. The maximum peaks agree very well. The differences on the other peaks and on the period of the tsunami can be explained by both the relatively poor bathymetric data available (interpolated from ETOPO1, Smith and Sandwell, 1997), as well as by the relatively low sampling rate of the tide gauge, which may hide some tsunami features.

Gutiérrez and Soley (1991) mention that "eyewitnesses reported a 'sudden' rise in sea level in Puntarenas, of about $1 \mathrm{~m}$, presumably due to the arrival of the crest of a tsunami wave to that port". Considering that the maximum height of the tsunami recorded in Quepos was about $25 \mathrm{~cm}$, it is unlikely that in Puntarenas the tsunami height could be four times that. The tsunami simulation at Puntarenas resulted in a maximum height of $20 \mathrm{~cm}$ at the pier (Fig. 7), more in line with the heights of the tsunami in Quepos.

Protti et al. (1995a) mention "from interviews with local residents $(. .$.$) at two estuaries, in Mata de Limón and at Pochote (...)$ the sea level reached half the high tide level for that estuaries, within approximately 5 min after the mainshock and went back to low tide level 5 min later. This behavior was observed for almost $3 \mathrm{~h}$ after the earthquake. To test these reports we ran a simulation of the arrival of the Cóbano tsunami at Ballena Bay, where the Pochote estuary is located, and our results do not confirm the reports, as can be seen in Fig. 8 . The difference may be a result of poor bathymetric data available inside Ballena Bay and therefore inside Pochote estuary, which could be masking some resonance effect.

\subsection{A tsunami originating in the Nicoya seismic gap}

Allowing $2.5 \mathrm{~m}$ of slip on the lower surface of the plate interface at the Nicoya seismic gap (a Mw $=7.8$ earthquake along a $5850 \mathrm{~km}^{2}$ fault surface), and using the co-seismic dislocation model of Mansinha and Smylie (1971), we produced the deformation pattern shown in Fig. 9. The main features of this deformation pattern are a region with up to $1.2 \mathrm{~m}$ of uplift just off the west coast of the Nicoya peninsula, parallel to a region of up to $20 \mathrm{~cm}$ of subsidence along the Gulf of Nicoya. The accumulation of the viscous part of this viscoelastic deformation over thousands of earthquakes cycles is what has created both the Nicoya peninsula, as well as the Gulf of Nicoya (Protti et al., 2001). The same process is involved in the genesis of the Osa peninsula and the Dulce gulf, some $200 \mathrm{~km}$ SE of the Nicoya peninsula.

Because the subsidence axis of the modeled co-seismic deformation induced by the next Nicoya earthquake coincides with the Nicoya Gulf (Fig. 9), Puntarenas experiences $9 \mathrm{~cm}$ of subsidence in

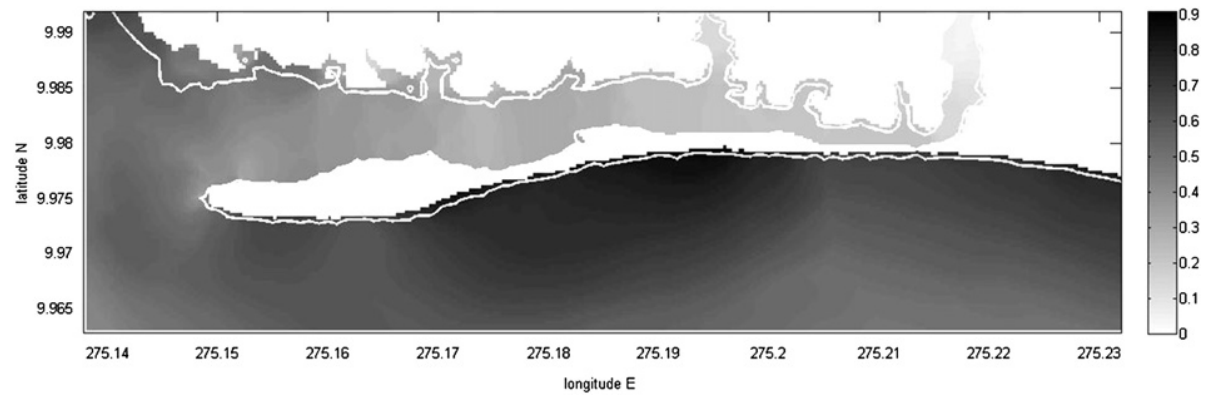

Fig. 10. Maximum tsunami heights and run-ups predicted by the model for Puntarenas from a Mw $=7.8$ earthquake under the Nicoya peninsula. Scale in meters. 


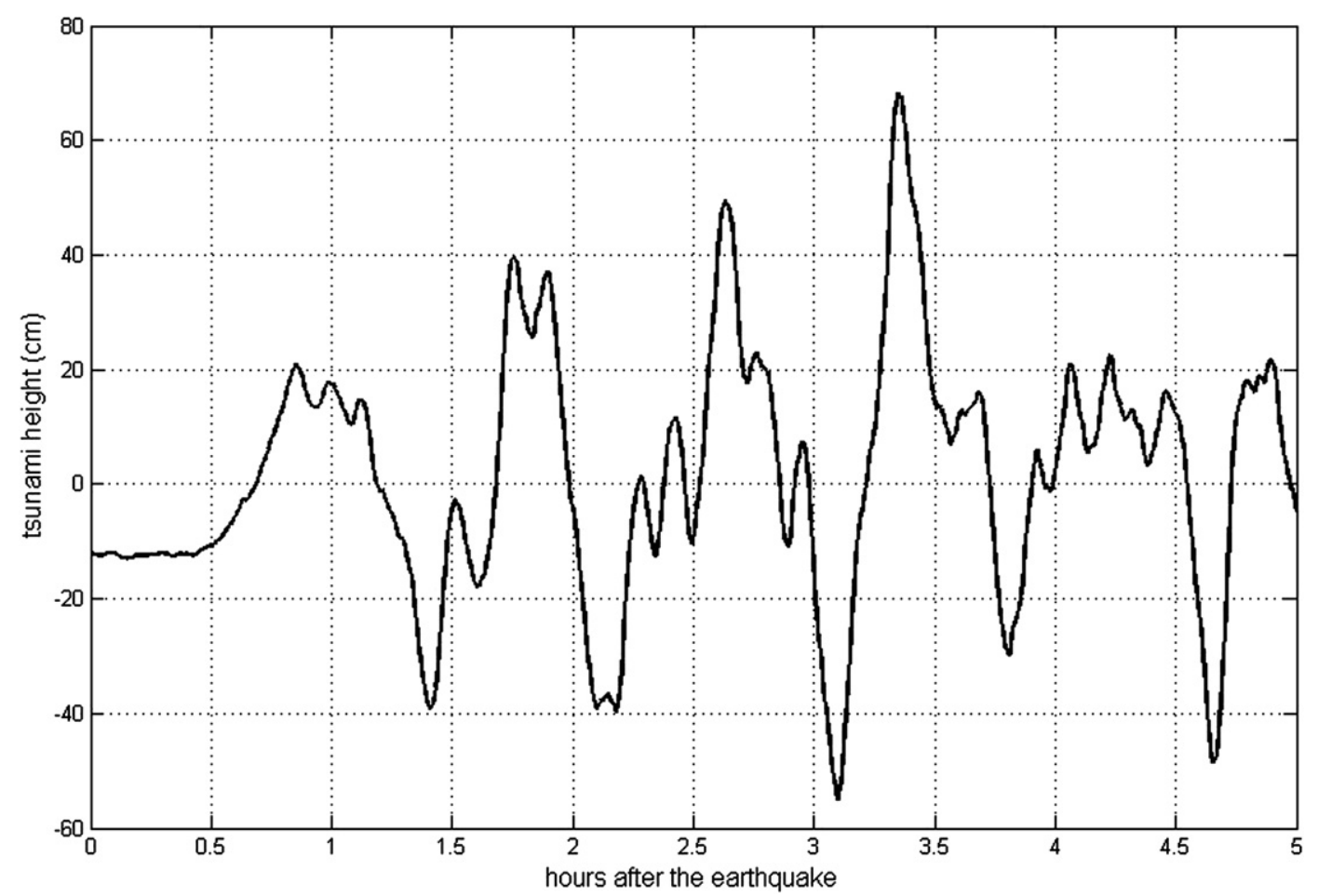

Fig. 11. Synthetic tsunami record at Puntarenas tourist pier resulted from a modeled $\mathrm{Mw}=7.8$ earthquake under the Nicoya peninsula.

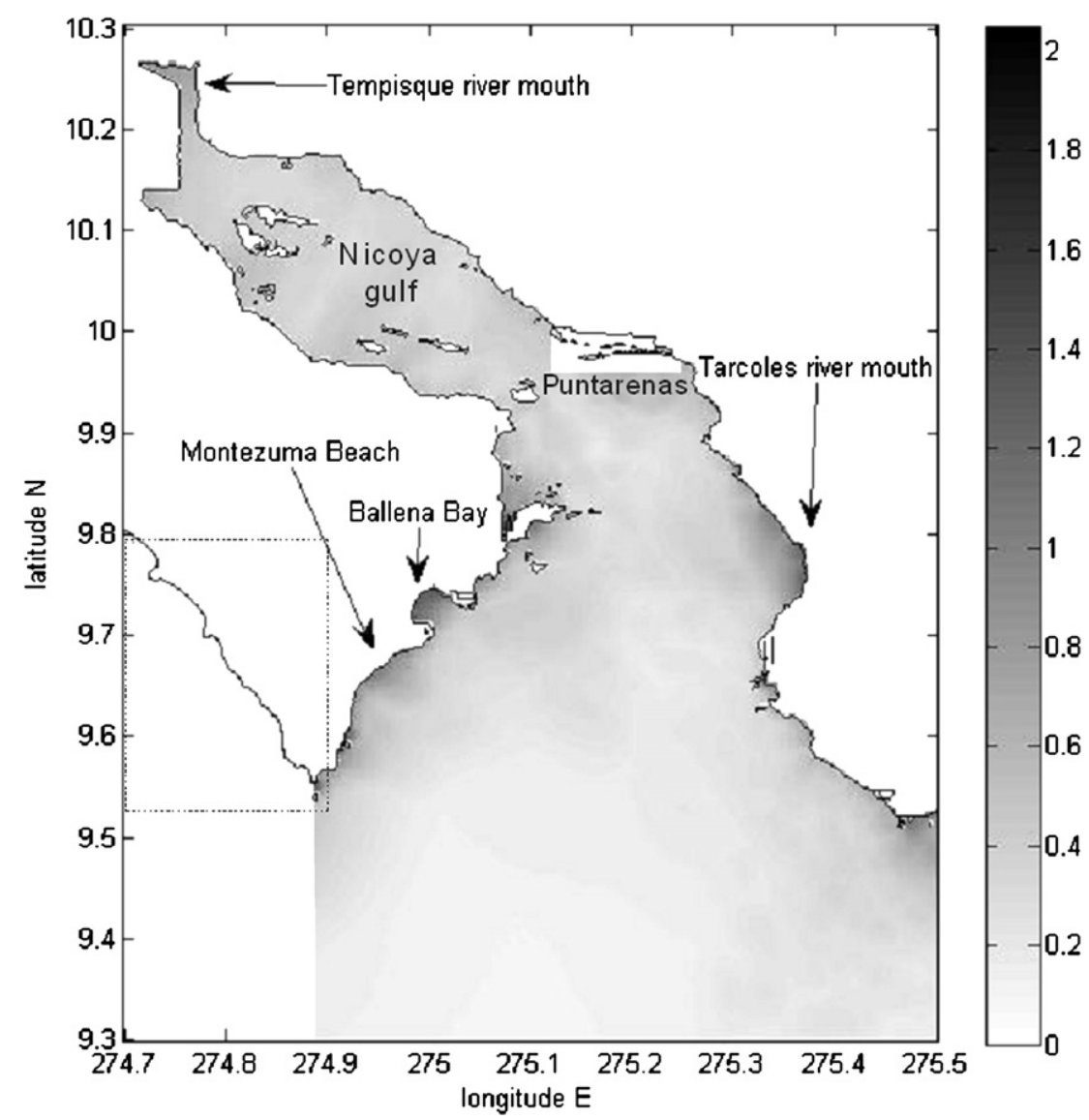

Fig. 12. Maximum tsunami heights predicted from a $\mathrm{Mw}=7.8$ earthquake under the Nicoya peninsula for the rest of the Nicoya gulf and surroundings. Scale in meters. Location of Tempisque and Tarcoles rivers mouths, Ballena Bay and Montezuma Beach are also shown. Dotted box shows area depicted on Fig. 13. 


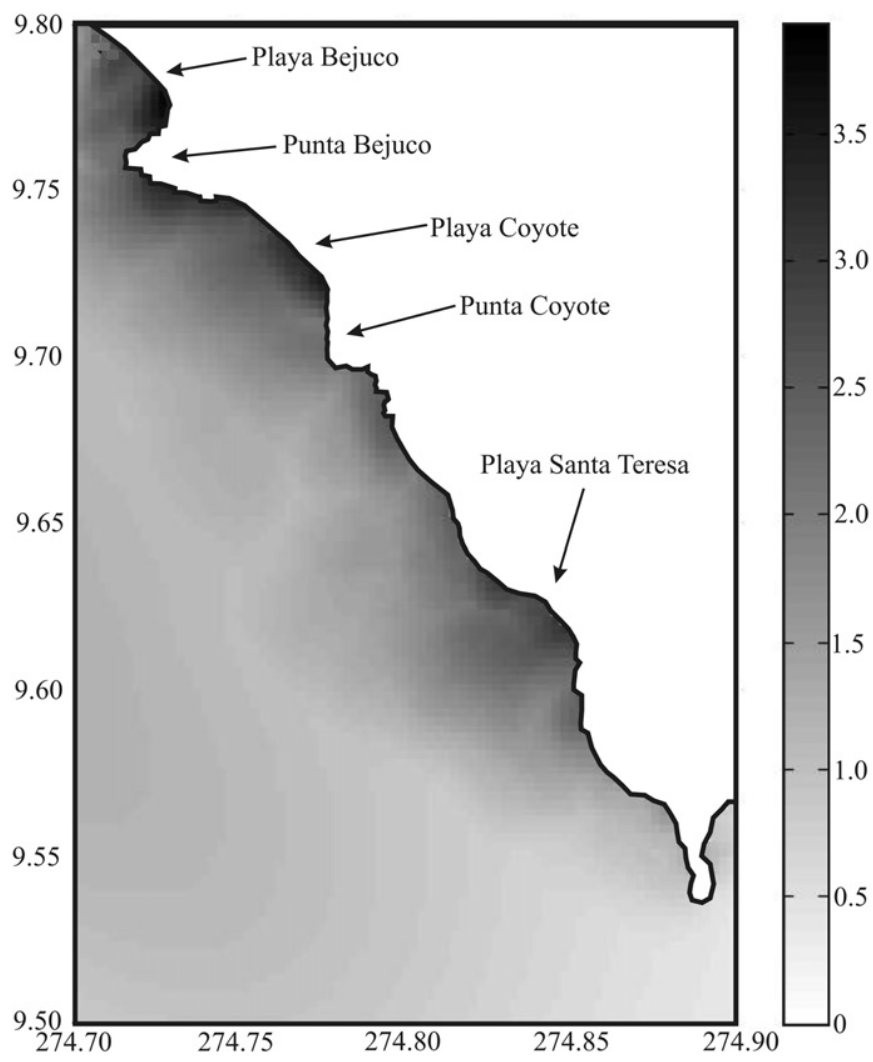

Fig. 13. Maximum tsunami heights predicted from a $M w=7.8$ earthquake under the Nicoya peninsula for a part of the western coast of the Nicoya Peninsula. Scale in meters.

the narrowest part and $12 \mathrm{~cm}$ of subsidence at the tip of the sand bar. These subsidence values are taken into account when calculating run-ups.

Fig. 10 shows the resultant maximum tsunami heights and runups at Puntarenas. The narrowest area of Puntarenas is not covered entirely by the tsunami; however, the model predicts tsunami runups of over $50 \mathrm{~cm}$ for this area, as well as for the area of Chacarita.

The model predicts tsunami penetration along the entire beachfront face of Puntarenas. The maximum run-ups are recorded eastward from the pier, with run-ups of over $70 \mathrm{~cm}$ (Fig. 10). It should noted that these run-ups are measured from the mean sea level, therefore, if at the time the tsunami arrives there is a low tide, the tsunami runup would be less than that shown; on the other hand, if the tsunami arrives at high tide, the run-ups will be much higher. Even at high tide these run-ups will barely have an impact beyond the main road along the beach. A concrete wall between this road and the beach would help reduce the potential impact of the tsunami.

The synthetic tsunami record for the tourist pier of Puntarenas, where water depth is only $57 \mathrm{~cm}$, is shown in Fig. 11. The maximum height of the tsunami (just over $60 \mathrm{~cm}$ ) could cause, at the very least, navigation problems. It is very important to note that the maximum height occurs almost three and a half hours after the quake, therefore authorities should take this in to account when deciding at what point to cancel an eventual tsunami warning in Puntarenas.

When analyzing the model results for other areas near Puntarenas, it is clear that the most sensitive regions within the Gulf of Nicoya (Fig. 12) are the Tempisque and Tárcoles river mouths. With regard to the southeast coast of the peninsula, Ballena Bay and Montezuma Beach recorded the highest run-ups predicted by the model, of about $1 \mathrm{~m}$.

For the entire Pacific coast of Costa Rica, the model predicts the higher run-ups for the areas close to the source of the tsunami generation. Fig. 13 shows the higher tsunami heights for a small part of the west coast of the Nicoya Peninsula. It is unfortunate that the available bathymetric data lacks sufficient resolution to make an accurate prediction for the rest of the coast.

\subsection{Another scenario for an earthquake in the Nicoya seismic gap}

We also modeled slip propagating on the shallower portion of the plate interface, almost to the trench. In this case we used a plane of $4550 \mathrm{~km}^{2}$ going from $5 \mathrm{~km}$ to nearly $12 \mathrm{~km}$ depth, with an angle of $15^{\circ}$, and a slip of $1.28 \mathrm{~m}$ (about half of what we used for the rupture on the average surface).

Given the low angle of the rupture surface, most of the deformation induced is horizontal with very little vertical deformation: maximum uplift of $+52 \mathrm{~cm}$, maximum subsidence $-26 \mathrm{~cm}$. The tsunami heights induced in this shallow portion of the seismogenic zone are very small in amplitude (around $30 \mathrm{~cm}$ ) compared with the results obtained from slip along the steeply dipping portion, and therefore can be neglected.

\section{Discussion and conclusions}

Ureña (2005) predicted somewhat smaller tsunami run-ups for Puntarenas, and less extensive than those obtained in this work. The discrepancy is mainly due to the bathymetries employed; Ureña (2005) digitized charts from the Defense Mapping Agency Topographic/Hydrographic Center (sic) with a scale of 1:300,000. We used digitized charts from the Costa Rica Geographic Institute in scales of $1: 100,000$ for Nicoya's Gulf and 1:12,500 for Puntarenas. Although the magnitudes of the seismic strains in Ureña (2005) are similar to those of this work, the localization of the deformation zone is different, and it is important to note that in Ureña (2005) Puntarenas lies outside of this zone.

Though the run-ups predicted in this work for Puntarenas do not exceed $1 \mathrm{~m}$, it is important to note that we have considered only one scenario, of medium severity, concerning the rupture of the seismic gap. Also, this work concerns only one source for a tsunami, the Nicoya seismic gap, while the impact from other sources will be different, as pointed out by Ortiz et al. (2001). For example, a tsunami originating in Colombia might have more serious consequences for Puntarenas.

It is important to remember also that the tsunami run-ups mentioned here do not take into account the tide, so different scenarios arise if the tide is high or low. If the tide is low, for example, the tsunami may go unnoticed by the population, since it does not exceed the tidal range for Puntarenas or for most locations on the Pacific coast of Costa Rica. Even in an extreme scenario, if the tide is high and coincides with an event like the spring tides and/or El Niño, the penetration and tsunami run-ups will be greater but still of fairly small magnitude and the impact would not be very severe.

We point out here that this study predicts that the most severely affected areas in Puntarenas are also those with the highest confluence of tourists: the area of the kiosks, the pier and the main bus station; therefore people working in those areas should be especially prepared.

Because of the particular geography of the city of Puntarenas, it is possible that its inhabitants and visitors could panic when the earthquake occurs and try to leave the city by the only terrestrial evacuation route: the narrow part of the sand bar named La Angostura. However, this study demonstrates that this route is one of the areas most vulnerable to a tsunami. It is therefore essential to develop a contingency plan covering the entire district of Puntarenas (the sand bar) for the eventual arrival of a tsunami. This plan must demarcate safe areas and evacuation routes that people and visitors should use. The population in general, and people working in 
the tourism industry in particular, must be properly educated about these routes. Based on the results of this work, the authors suggest as safe areas buildings of two or more floors in good condition, and the areas surrounding the Puntarenas Cathedral and the Lito Perez Stadium, as they are the highest places on the sand bar. This planning should be done in parallel with the clear explanation that a catastrophic tsunami from the rupture of the Nicoya seismic gap is not likely to occur, and therefore there is no reason for panic. We believe the plan should still be established because it might prove to be very effective in the event of a large trans-oceanic tsunami.

We must not forget that the consequences of the earthquake itself may be important for Puntarenas, as it is located within the zone of high seismic accelerations. If damage caused by the earthquake combines with fear of a tsunami, the resulting panic could be magnified. The city of Puntarenas is built on a narrow sand bar just above sea level. Ground shaking due to an M 7.8 earthquake on the adjacent Nicoya Peninsula could be quite severe and might produce liquefaction and even lateral spreading of the sand bar. Although these effects could result in substantial subsidence in some areas of the city, changing the coastal elevation relative to sea level, and thus altering the potential tsunami inundation pattern, the only effect observed there during the 1950 earthquake was sliding and subsidence of a few portions of the north coast, toward the estuary, not exceeding half a meter (Louderback, 1951; Marshall, 1991; Protti et al., 1995a and Protti et al., 2001).

In this work the tsunami run-ups for other coastal locations in addition to Puntarenas were not calculated in detail, due to the lack of fine bathymetry. Nevertheless, the model results indicate that the tsunami run-ups in the area of Samara could be significant. According to witnesses' reports, the tsunami caused by the 1950 earthquake under the Nicoya peninsula ( $\mathrm{Mw}=7.7$, Pacheco and Sykes, 1992), had run-ups between 2 and $4 \mathrm{~m}$ in that area (Protti et al., 2001). Today, the beaches of the southwest coast of the peninsula are heavily visited by tourists both domestic and foreign; cause for concern that should not be ignored by authorities or scientists. One advantage is that these coastal areas will also experience co-seismic uplift of up to $2 \mathrm{~m}$ (Protti et al., 2001) and so the potential for damage will be reduced.

Another region that cannot ignore the results of this study is Paquera, southwest across the gulf from Puntarenas, due mainly to the maritime traffic it receives. The model predicts tsunami heights there close to $1 \mathrm{~m}$, which may affect navigation and could damage small boats. This area lies within the co-seismic subsidence region which could further increase the potential for negative effects.

There is no question that an earthquake of important magnitude will occur in the Nicoya seismic gap: energy continues to accumulate in this segment of the subduction zone every day and needs to be released at some point, therefore, coastal communities and the country's authorities must be made aware of this fact. We emphasize that it is imperative to develop contingency plans and warning systems for the city of Puntarenas and the southwest coast of the Nicoya Peninsula.

\section{Acknowledgments}

This is a contribution of the project "Sistema de Monitoreo Geodinámico de Nicoya (SISMOGENICO)" from OVSICORI-UNA. We want to thank Dr. Modesto Ortiz, at CICESE in Ensenada, Baja California, México, for providing the bathymetries and numerical models used in this work. We want to thank also Alejandro Gutiérrez, at UNA, Costa Rica, for providing the tide record of the 1990 Cóbano tsunami in Quepos. Earlier drafts of this manuscript were also improved by Alejandro Gutiérrez and by Javier Pacheco at OVSICORI-UNA. James Kellogg, Luiz D'el-Rey and an anonymous reviewer provided excellent suggestion to improve it.

\section{References}

Barquero, R., Boschini, I. (Eds.), 1991. La crisis sísmica del Golfo de Nicoya y eventos relacionados, Costa Rica, 1990. Informe técnico de la. Red Sismológica Nacional (R.S.N.-ICE), Costa Rica.

De Mets, C., Gordon, R.G., Argus, D.F., Stein, S., 1990. Current plate motions. Geophys. J. Int. 101, 425-478.

DeShon, H.R., Schwartz, S.Y., Newman, A.V., González, V., Protti, M., Dorman, L.M., Dixon, T.H., Sampson, D.E., Flueh, E.R., 2006. Seismogenic zone structure beneath the Nicoya peninsula, Costa Rica, from three-dimensional local earthquake P- and S-wave tomography. Geophys. J. Int. 164, 109-124.

Fan, G.W., Beck, S.L., Wallace, T.C., 1993. The seismic source parameters of the 1991 Costa Rica aftershock sequence: evidence for a transcurrent plate boundary. Jour. Geophys. Res. 98, 15759-15778.

Farreras, S., 1997. Tsunamis en México. In: Lavín, M.F. (Ed.), Contribuciones a la Oceanografía Física en México. Unión Geofísica Mexicana, pp. 75-98. Monografía No. 3.

Fisher, D.M., Gardner, T.W., Marshall, J.S., Montero, W., 1994. Kinematics associated with Late tertiary and quaternary deformation in central Costa Rica: western boundary of the Panamá microplate. Geology 22, 263-266.

Goes, S.D.B., Velasco, A.A., Schwartz, S., Lay, T., 1993. The April 22, 1991, Valle de la Estrella, Costa Rica ( $\mathrm{Mw}=7.7$ ) earthquake and its tectonic implications: a broadband seismic study. J. Geophys. Res. 98, 8127-8142.

Gonzalez, V., Protti, M., 2005. Afinamiento del Potencial Sísmico y Monitoreo de la Brecha Sísmica de Nicoya. Ambientico. ISSN: 1409-214X 147. ISSN: 1409-214X, 13-16.

Goto, C., Ogawa, Y., Shuto, N., Imamura, F., 1997. IUGG/IOC TIME Project: “Numerical Method of Tsunami Simulation with the Leap-Frog Scheme". Intergovernmental Oceanographic Commission of UNESCO, Paris. Manuals and Guides \#35.

Gutiérrez, A., Soley, F., 1991. Análisis de los registros de nivel del mar correspondientes al terremoto de Cóbano del 23-03-90. Revista Geofísica 35, 181-196.

Güendel, F., Pacheco, J., 1992. The 1990-1991 seismic sequence across central Costa Rica: evidence for the existence of a micro-plate boundary connecting the Panama deformed belt and the Middle America trench. Eos Trans. Am. Geophys. Un 73, 399.

Ide, S., Imamura, F., Yoshida, Y., Abe, K., 1993. Source characteristics of the Nicaraguan tsunami earthquake of September 2, 1992. Geophys. Res. Lett. 20, 863-866. doi:10.1029/93GL00683.

Iinuma, T., Protti, M., Obana, K., Gonzalez, V., van der Laat, R., Kato, T., Miyasaki, S., Kaneda, Y., Hernandez, E., 2004. Inter-plate coupling in the Nicoya Peninsula, Costa Rica, as deduced from a trans-peninsula GPS experiment. Earth Planetary Sci. Lett. 223, 203-212.

Instituto Geográfico Nacional (IGN), 2005. División Territorial Administrativa de la República de Costa Rica, Comisión Nacional de División Territorial Administrativa.

Jacob, K.H., Pacheco, J., 1991. The M-7.4 Costa Rica earthquake of April 22, 1991: tectonic setting, teleseismic data, and consequences for seismic hazard assessment. Earthquake Spectra 7 (B).

Louderback, G.D. (Ed.), 1951, Seismological Notes: Bulletin of the Seismological Society of America, vol. 41, p. 68.

Lundgren, P., Protti, M., Donnellan, A., Heflin, M., Hernández, E., Jefferson, D., 1999. Seismic cycle and plate margin deformation in Costa Rica: GPS observations from 1994 to 1997. Jour. Geophys. Res. 104 (B12), 28915-28926.

Mansinha, L., Smylie, E., 1971. The displacement field of inclined faults. Bull. Seismological Soc. America 61, 1433-1440.

Marshall, J.S., 1991, Neotectonics of the Nicoya Peninsula, Costa Rica: A Look at Forearc Response to Subduction at the Middle America Trench, [M.S. Thesis]: University of California Santa Cruz, p. 96

Marshall, J.S., Anderson, R.S., 1995. Quaternary uplift and seismic cycle deformation, Península de Nicoya, Costa Rica. Geol. Soc. America Bull. 107, 463-473.

Marshall, J.S., Fisher, D.M., Gardner, T.W., 2000. Central Costa Rica deformed belt: Kinematics of diffuse faulting across the western Panama block. Tectonics 19, 468-492.

Newman, A., Schwartz, S., Gonzalez, V., DeShon, H., Protti, M., Dorman, L., 2002. Along-strike variability in the seismogenic zone below Nicoya Peninsula, Costa Rica. Geophys. Res. Lett. 29 (20).

Nishenko, S.P., 1985. Seismic Potential for large and great interplate earthquakes along the Chilean and southern Peruvian margins of South America: a quantitative reappraisal. Jour. Geophys. Res. 90 (B5), 3589-3615.

Norabuena, E., Dixon, T.H., Schwartz, S.Y., DeShon, H.R., Protti, M., Dorman, L., Flueh, E.R., González, V., Lundgren, P., Newman, A., Pollitz, F., Sampson, D., 2004. Geodetic and seismic constraints on some seismogenic zone processes in Costa Rica. J. Geophys. Res. 109, B11403. doi:10.1029/2003JB002931.

Ortiz, M., Fernández-Arce, M., Rojas, W., 2001. Análisis de riesgo de inundación por tsunamis en Puntarenas, Costa Rica. GEOS 21 (2), 108-113.

Pacheco, J., Sykes, L.R., 1992. Seismic moment catalog of large shallow earthquakes, 1900 to 1989. Bull. Seismological Soc. America 82, 1306-1349.

Ponce, D.A., Case, J.E., 1987. Geophysical interpretation of costa Rica, in: Mineral Resources assessment of the Republic of costa Rica, U.S. Geol. Surv. Misc. Invest. I-1865, 8-17.

Protti-Quesada, J. M., 1991. Correlation between the age of the subducting Cocos plate and the geometry of the Wadati-Benioff zone under Nicaragua and Costa Rica. MSc. dissertation, University of California, Santa Cruz, p. 66. 
Protti, M., Schwartz, S., 1994. Mechanics of back arc deformation in Costa Rica: Evidence from an aftershock study of the April 22, 1991, Valle de la Estrella, Costa Rica, earthquake (Mw = 7.7). Tectonics 13 (5), 1093-1107.

Protti, M., and 14 other co-authors, 1995a. The March 25, $1990(\mathrm{Mw}=7.0 \mathrm{Ml}=6.8)$ earthquake at the entrance of the Nicoya Gulf, Costa Rica: its prior activity, foreshocks, aftershocks and triggered seismicity. Jour. Geophys. Res. 100 (B10), 20345-20358.

Protti, M., Güendel, F., McNally, K., 1995b. Correlation between the age of the subducting Cocos Plateand the geometry of the Wadati-Benioff zone under Nicaragua and costa Rica. In: Mann, P. (Ed.), Geologic and Tectonic Development of the Caribbean Plate Boundary in Southern Central America. Geological Society of America, Boulder, Colorado, pp. 309-326. Special Paper 295.
Protti, M., Güendel, F., Malavassi, E., 2001. Evaluación del potencial sísmico de la Península de Nicoya. Editorial Fundación UNA, Heredia, Costa Rica.

Protti, M., González, V., 2007. Active subduction on both coasts of costa Rica does not represent an important tsunami hazard. Eos Trans. AGU 88 (23) Jt. Assem. Suppl., Abstract 52A-04.

Satake, K., 1994. Mechanism of the 1992 Nicaragua tsunami earthquake. Geophys. Res. Lett. 21 (23), 2519-2522. doi:10.1029/94GL02338.

Smith, W.H.F., Sandwell, D.T., 1997. Global Seafloor Topography from Satellite Altimetry and ship depth Soundings. Science 277, 1956-1962.

Ureña, F., 2005. Puntarenas y Quepos, Proyecto TIME. Simulación de un tsunami eventual frente a las costas de la Península de Nicoya y su influencia en el Golfo de Nicoya, vol. 9. Repertorio Científico de la Escuela de Ciencias Exactas y Naturales de la UNED (1), pp. 48-54. 